\title{
Faktor-Faktor yang Mempengaruhi Perilaku Dosen STAI Auliaurrasyidin Tembilahan dalam Memilih Produk Bank Syariah
}

\author{
*Siti Zariah ${ }^{1, a}$ \\ 1) Pascasarjana UIN Sultan Syarif Kasim Riau, Indonesia

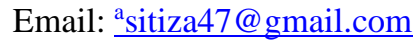

\begin{tabular}{ll}
\hline DOI: & \multicolumn{1}{c}{ Cara Mensitasi Artikel ini: } \\
$\underline{\text { https://doi.org/10.469 }}$ & $\begin{array}{l}\text { Zariah. S. (2021). Faktor-faktor yang mempengaruhi perilaku dosen STAI Auliaurrasyidin } \\
\text { 63/jam.v4i2.439 }\end{array}$ \\
& $\begin{array}{l}\text { Tembilahan dalam memilih produk Bank Syariah. AL-Muqayyad, 4(2), 108-127. } \\
\text { https://doi.org/10.46963/jam.v4i2.439 }\end{array}$ \\
\hline
\end{tabular}

Keywords:
Behavior, Decision
Sharia Bank

Kata Kunci:

Perilaku, Keputusan,

Bank Syariah

\section{ABSTRACT}

This research was motivated by The sharia economy is now entering the world of education, in addition to banks and other non-bank financial institutions that are busy adding the "sharia" label to their institutions. TThe purpose of this research is to find out and analyze The factors that influence the behavior of STAI Lecturer Auliaurrasyidin through cultural, social, personal, psychological and knowledge factors as moderating variables in choosing Islamic bank products in Tembilahan. This research was conducted at STAI Auliaurrasyidin Tembilahan with the number of respondents as many as 32 permanent lecturers. The method used in this quantitative research is the survey method. This research is a mixed research, which combines quantitative and qualitative research. The results of the study based on the correlation coefficient analysis test showed that the level of influence of the variables of consumer behavior factors, namely cultural factors, social factors, personal factors and psychological factors simultaneously on the decision of STAI Lecturer Auliaurrasyidin Tembilahan in choosing Islamic bank products was worth 0.776 and the level of the relationship was in the category " strong" or "high" while the knowledge moderation variable is worth 0.411 and the level of the relationship is in the "medium" or "fair" category.

Informasi Artikel: Diterima: 02/12/2021

Direvisi:

-

Diterbitkan $30 / 12 / 2021$

*Corresponding Author sitiza47@gmail.com

\section{ABSTRAK}

Penelitian ini dilatarbelakangi oleh perekonomian syariah kini merambah ke dunia pendidikan, selain perbankan dan lembaga keuangan non bank lainnya yang sibuk menambahkan label "syariah" pada lembaganya. Tujuan penelitian ini adalah untuk mengetahui dan menganalisis faktor-faktor yang mempengaruhi perilaku Dosen STAI Auliaurrasyidin melalui faktor budaya, sosial, pribadi, psikologi dan pengetahuan sebagai variabel moderasi dalam memilih produk bank syariah di Tembilahan. Penelitian ini dilaksanakan di STAI Auliaurrasyidin Tembilahan dengan jumlah responden sebanyak 32 orang Dosen Tetap. Metode yang digunakan dalam penelitian kuantitatif ini adalah metode survey. Penelitian ini adalah penelitian gabungan (mixed reseach), yaitu yang menggabungkan penelitian kuantitatif dan kualitatif. Hasil penelitian berdasarkan uji Analisis koefisien korelasi menunjukkan bahwa tingkat pengaruh variabel faktor-faktor perilaku Konsumen yaitu faktor budaya, faktor sosial, faktor pribadi dan faktor psikologi secara simultan terhadap keputusan Dosen STAI Auliaurrasyidin Tembilahan dalam memilih produk bank Syariah bernilai 0,776 dan tingkat hubungannya dalam kategori " kuat" atau " tinggi" sedangkan variabel moderasi pengetahuan bernilai 0,411 dan tingkat hubungannya dalam kategori "sedang" atau "cukup". 
Faktor-Faktor yang Mempengaruhi Perilaku ......

\section{PENDAHULUAN}

Peningkatan kehidupan masyarakat daerah setempat erat diidentifikasi dengan kegiatan ekonomi. Tingkah laku masyarakat setempat dalam memenuhi kebutuhan sehari-hari terlihat ketika bermualamah. Salah satunya, membuat investasi yang diandalkan untuk membantu memenuhi kebutuhan mereka di kemudian hari.

Beberapa model investasi harus dimungkinkan dengan menabung, deposito, dan menanamkan modal saham. Tindakan spekulasi ini secara tegas diidentikkan dengan lembaga keuangan konvensional dan syariah. Kepentingan lembaga moneter saat ini sangat diminati oleh masyarakat umum sebagai kebutuhan penunjang di kemudian hari, menempatkan investasi ke dalam lembaga keuangan syariah, misalnya bank syariah menjadi pilihan utama saat ini.

Terdapat sebagian aspek yang pengaruhi sikap konsumen dalam membeli sesuatu produk ataupun jasa. "Faktor-faktor yang mempengaruhi perilaku konsumen, menurut Kotler dan Armstrong, meliputi pengaruh budaya, sosial, pribadi, serta psikologis." (Philip Kotler dan Gary Amstrong, 2012: 197-207). Dalam riset ini faktor perilaku konsumen dalam memilih produk diukur melalui variabel budaya, sosial, pribadi, psikologi dan penambahan variabel pengetahuan. Adapun alasan peneliti menambahkan variabel pengetahuan adalah pertama, variabel ini merupakan suatu proses yang dapat mempengaruhi keputusan dalam memilih produk Bank Syariah. Kedua, penelitian sebelumnya membuktikan adanya berpengaruh positif antara keputusan sehingga peneliti ingin menguji kembali apakah hasilnya akan sama jika peneliti melakukan penelitian di lokasi dan responden yang berbeda.

Di Indonesia, pengetahuan masyarakat terhadap berbagai barang serta sistem bank syariah dikatakan masih cukup rendah. Perihal ini merupakan salah satu hambatan terbesar bagi perkembangan bank syariah di Indonesia. Secara internasional, bank syariah disebut sebagai Islamic Banking. Semacam bank konvensional, Bank Syariah punya peran utama buat menghimpun dana publik, serta menyalurkan dana tersebut kembali ke publik, serta sediakan layanan perbankan lainnya. (Kasmir, 2015: 11) Pengetahuan sosialisasi publik tentang produk serta sistem bank syariah masih sangat terbatas. Tentang ini dikuatkan oleh statistik dan dikeluarkan oleh Otoritas Jasa Keuangan (OJK) pada mula tahun 2021, yang menunjukkan bahwa terdapat 14 Bank Umum Syariah (BUS), 20 Unit Usaha Syariah (UUS), serta 207 Bank Perkreditan Rakyat Syariah di Tanah Air (BPRS), dari jumlah tersebut ada sebanyak 65\% pangsa pasar Bank Syariah dikuasai oleh BUS serta 32,36\% ialah UUS serta sisanya merupakan BPRS. Perbandingan selama 5 periode (2016-2020) terakhir, aset perbankan syariah meningkat 10,15\%, Dana Pihak Ketiga (DPK) meningkat 13,34\%, dan pembiayaan meningkat 10,09\%. Terlepas dari kenyataan bahwa kebanyakan warga Indonesia merupakan Muslim, namun pertumbuhan produk syariah berjalan secara bertahap serta tertinggal dari bank konvensional.

Dari data tersebut menunjukkan bahwa pendirian bank syariah belum sepenuhnya mengubah perilaku dan pengetahuan masyarakat Indonesia, khususnya masyarakat

\section{Al-Muqayyad}

Vol 4 No 2 (2021) 
Muslim, mengenai perbankan syariah. Karena minimnya informasi publik mengenai perbankan syariah, bank konvensional mendominasi lebih dari bank syariah, dan perbankan syariah memiliki lebih banyak rintangan dan masalah dalam perkembangannya. Tidak cuma itu, aturan perundang-undangan yang masih berlaku belum seluruhnya mengakomodir sistem operasional perbankan syariah, jaringan layanan bank syariah masih terbatas, sumber daya manusia dan teknologi perbankan syariah terbatas. (Zainul Arifin, 2010: 214-215). Sebab perbankan syariah mengenakan sistem yang berbeda dari bank konvensional, paling utama dari sudut pandang pelaksanaan hukum Islam di dalamnya. Syariah (hukum Islam) berupaya buat tingkatkan kesejahteraan masyarakat dengan menjamin keyakinan, kehidupan, kecerdasan, generasi, serta kesejahteraan.

Terlepas dari kekurangan serta kelemahan yang punyai perbankan syariah di Indonesia dikala ini, butuh rasanya buat memandang macam apa posisi akademisi muslim khususnya para pengajar (Dosen) tentang perbankan syariah dikala ini. Pengetahuan terhadap perbankan syariah jua bakal jadi pertimbangan serta acuan dalam memetakan segmentasi pasar industri keuangan syariah, karna mereka memiliki posisi strategis buat pengaruhi serta meyakinkan para mahasiswa dan publik tentang keunggulan Bank Syariah sehingga menolong percepatan pengembangan Bank Syariah di Indonesia dan juga mempengaruhi keputusan dalam memilih produk Bank Syariah.

Perekonomian syariah kini merambah ke dunia pendidikan, selain perbankan serta lembaga keuangan non bank yang lain yang giat meningkatkan logo "syariah" pada lembaganya. Ada sejumlah perguruan tinggi yang telah mengembangkan jurusan ekonomi Islam, serta kampus-kampus khusus yang didedikasikan untuk studi ekonomi Islam. Terdapat pula kursus perbankan Islam yang ada di kampus-kampus universal. Peningkatan kampus ataupun jurusan baru guna sumber ilmiah ekonomi syariah terus menjadi menambahkan khazanah keilmuan tentang ekonomi syariah. Banyak pihak yang mengapresiasi program riset ini sebab membolehkan mahasiswa buat belajar ekonomi syariah tanpa mesti jauh-jauh belajar ke luar negara.

Sekolah Tinggi Agama Islam Auliaurrasyidin juga menyediakan layanan tabungan wadiah bagi mahasiswa dan Dosen dengan dibukanya Bank Mini Syariah (BMS), tetapi hanya sebagian mahasiswa ekonomi syariah dan sebagian Dosen saja yang ikut berpartisipasi menabung. Hal ini menunjukkan bahwa tidak hanya pemahaman masyarakat yang terbatas terhadap produk Bank Syariah tetapi Dosen juga memiliki keterbatasan tentang informasi dan pengetahuan mereka terhadap produk Bank Syariah.

Pengetahuan Dosen tentang bank syariah juga akan mempengaruhi cara pandangnya terhadap keputusan menggunakan produk bank syariah. Secara sederhana, pandangan Dosen mengenai perbankan syariah didasarkan pada pengetahuan mereka terhadap produk perbankan syariah. Jika pengetahuan seseorang mengenai bank syariah secara objektif salah, persepsi seseorang tentang bank syariah pasti salah juga. Dosen merupakan salah satu sumber informasi mengenai pengetahuan tentang produk Bank 
Faktor-Faktor yang Mempengaruhi Perilaku ......

Syariah bagi mahasiswa. Akibatnya, memahami elemen-elemen yang mempengaruhi penilaian Dosen dalam memilih produk Bank Syariah sangat penting bagi kemajuan bank syariah baik dari segi pembelajaran ataupun pertumbuhan bank syariah itu sendiri.

\section{METODE}

Jenis penelitian dalam penelitian ini adalah penelitian gabungan (mixed reseach), yang menggabungkan data kuantitatif dan kualitatif dengan menggunakan pendekatan konvergen, dimana dilakukan dua pendekatan berdasarkan metode kuantitatif dan kualitatif. Metode kuantitatif adalah deskriptif, sedangkan pendekatan kualitatif adalah falsafah asosiatif. Pendekatan penelitian ini berupaya menggali faktor-faktor yang mempengaruhi perilaku keputusan Dosen STAI Auliaurrasyidin dalam memilih produk Bank Syariah di Tembilahan

Metode penelitian yang digunakan dalam penelitian ini adalah survei. Metode survei adalah jenis penelitian yang dilakukan pada populasi besar atau kecil, namun data yang diteliti adalah sampel dari data populasi tersebut. (Sugiyono, 2012: 7). Metode kualitatif meliputi pengambilan informan yang dijadikan sumber informasi data. Informan adalah sumber informasi dalam penelitian ini, dan pemilihan informan sumber data dalam penelitian kualitatif didasarkan pada siapa yang paling tahu tentang pertanyaan dan dapat memberikan informasi yang dapat dipercaya atau valid. Yang ditanyakan adalah terkait hasil penelitian kuantitatif. Informan tersebut yaitu Dosen tetap ekonomi syariah yang memiliki rekening Bank Syariah.

Dasar digunakan untuk menunjuk informan menggunakan teknik bola salju yaitu strategi dasar bola saju (snowball). Dimulai dengan menetapkan satu atau lebih orang kunci (key informant) dan melakukan wawancara dengan mereka secara bertahap atau proses. Tempat penelitian Kampus STAI Auliaurrasyidin Tembilahan digunakan untuk studi lapangan (field research).

Populasi dalam penelitian ini adalah Dosen tetap STAI Auliaurrasyidin Tembilahan Kabupaten Indraggiri Hilir berjumlah 32 orang. Pengambilan sampel ini dilakukan menggunakan teknik atau metode sensus, dimana sampel diambil secara keseluruhan dari empat jurusan di STAI Auliaurrasyidin yang berjumlah 32 orang dosen.

Teknik pengumpulan data kuantitatif diperoleh melalui kegiatan penyebaran kuesioner atau angket berupa daftar pernyataan yang mengacu pada variabel dan indikator faktor-faktor yang mempengaruhi keputusan Dosen STAI Auliaurrasyidin dalam memilih produk Bank Syariah. Jenis angket berupa checklist untuk memilih pernyataan, tanpa memberikan ruang bagi responden untuk mengajukan opsi tambahan di luar opsi yang disajikan. Skala pengukuran yang digunakan dalam penelitian ini adalah skala pengukuran likert dan guttman. Teknik analisis yang digunakan yaitu menggunakan regresi linier berganda dan regresi moderasi. Teknik pengumpulan data Kualitatif diperoleh melalui wawancara. Teknik analisis data yang digunakan berdasarkan pendapat Miles dan Huberman.

\section{Al-Muqayyad}

Vol 4 No 2 (2021) 


\section{HASIL DAN PEMBAHASAN}

\section{Uji Validitas}

\section{Uji Validitas Instrumen Kuesioner Skala Likert}

Analisis tabel berikut menunjukkan hasil analisis validitas uji analisis instrumen data atas pernyataan 32 responden, berdasarkan hasil pengolahan data melalui SPSS. 22:

Tabel I. 1

Hasil Uji Validitas Instrumen Penelitian Skala Likert

\begin{tabular}{|c|c|c|c|c|}
\hline Variabel & $\begin{array}{c}\text { Item } \\
\text { Instrumen } \\
\text { Pertanyaan }\end{array}$ & $\begin{array}{l}\text { Corrected Item } \\
\text { Total Correlation } \\
(r \text { hitung })\end{array}$ & $\begin{array}{c}\text { Harga } r_{\text {tabel }} \\
\quad(\alpha=5 \%)\end{array}$ & $\begin{array}{c}\text { Keterangan } \\
\text { Hasil }\end{array}$ \\
\hline \multirow{7}{*}{$\begin{array}{c}\text { Faktor } \\
\text { Budaya } \\
\left(\mathrm{X}_{1}\right)\end{array}$} & $\mathrm{P} 1$ & 0,638 & 0,349 & Valid \\
\hline & $\mathrm{P} 2$ & 0,617 & 0,349 & Valid \\
\hline & P3 & 0,592 & 0,349 & Valid \\
\hline & $\mathrm{P} 4$ & 0,573 & 0,349 & Valid \\
\hline & P5 & 0,678 & 0,349 & Valid \\
\hline & P6 & 0,685 & 0,349 & Valid \\
\hline & P7 & 0,581 & 0,349 & Valid \\
\hline \multirow{6}{*}{$\begin{array}{c}\text { Faktor } \\
\text { Sosial }\left(\mathrm{X}_{2}\right)\end{array}$} & $\mathrm{P} 1$ & 0,626 & 0,349 & Valid \\
\hline & $\mathrm{P} 2$ & 0,550 & 0,349 & Valid \\
\hline & P3 & 0,631 & 0,349 & Valid \\
\hline & $\mathrm{P} 4$ & 0,574 & 0,349 & Valid \\
\hline & P5 & 0,696 & 0,349 & Valid \\
\hline & P6 & 0,768 & 0,349 & Valid \\
\hline \multirow{13}{*}{$\begin{array}{c}\text { Faktor } \\
\text { Pribadi }\left(\mathrm{X}_{3}\right)\end{array}$} & $\mathrm{P} 1$ & 0,644 & 0,349 & Valid \\
\hline & $\mathrm{P} 2$ & 0,466 & 0,349 & Valid \\
\hline & P3 & 0,440 & 0,349 & Valid \\
\hline & $\mathrm{P} 4$ & 0,561 & 0,349 & Valid \\
\hline & P5 & 0,402 & 0,349 & Valid \\
\hline & P6 & 0,489 & 0,349 & Valid \\
\hline & P7 & 0,494 & 0,349 & Valid \\
\hline & P8 & 0,494 & 0,349 & Valid \\
\hline & P9 & 0,477 & 0,349 & Valid \\
\hline & P10 & 0,451 & 0,349 & Valid \\
\hline & P11 & 0,671 & 0,349 & Valid \\
\hline & $\mathrm{P} 12$ & 0,491 & 0,349 & Valid \\
\hline & $\mathrm{P} 13$ & 0,624 & 0,349 & Valid \\
\hline \multirow{3}{*}{$\begin{array}{c}\text { Faktor } \\
\text { Psikologi } \\
\left(\mathrm{X}_{4}\right)\end{array}$} & P1 & 0,708 & 0,349 & Valid \\
\hline & $\mathrm{P} 2$ & 0,856 & 0,349 & Valid \\
\hline & P3 & 0,794 & 0,349 & Valid \\
\hline
\end{tabular}


Faktor-Faktor yang Mempengaruhi Perilaku ......

\begin{tabular}{ccccc} 
& P4 & 0,700 & 0,349 & Valid \\
& P5 & 0,657 & 0,349 & Valid \\
& P6 & 0,647 & 0,349 & Valid \\
& P7 & 0,717 & 0,349 & Valid \\
& P8 & 0,679 & 0,349 & Valid \\
& P9 & 0,654 & 0,349 & Valid \\
& P10 & 0,790 & 0,349 & Valid \\
& P11 & 0,744 & 0,349 & Valid \\
& P12 & 0,815 & 0,349 & Valid \\
\hline \multirow{6}{*}{ Keputusan } & P1 & 0,633 & 0,349 & Valid \\
Konsumen & P2 & 0,439 & 0,349 & Valid \\
& P3 & 0,414 & 0,349 & Valid \\
& P4 & 0,432 & 0,349 & Valid \\
& P5 & 0,655 & 0,349 & Valid \\
& P6 & 0,467 & 0,349 & Valid \\
& P9 & 0,503 & 0,349 & Valid \\
& P10 & 0,615 & 0,349 & Valid \\
& P11 & 0,528 & 0,349 & Valid \\
& P12 & 0,559 & 0,349 & Valid \\
& P13 & 0,643 & 0,349 & Valid \\
& P14 & 0,534 & 0,349 & Valid \\
& P15 & 0,715 & 0,349 & Valid \\
& 0,463 & 0,349 & Valid \\
& 0,618 & 0,349 & Valid \\
\hline
\end{tabular}

Sumber: Data primer yang diolah, 2021

Dari data di atas dapat diambil suatu kesimpulan bahwa semua instrumen data penelitian terutama terkait dengan variabel Faktor Budaya (X1), Faktor Sosial (X2), Faktor Pribadi (X3), Faktor Psikologi (X4) dan Keputusan Konsumen (Y) adalah valid dan layak untuk dianalisis, karena nilai $r_{\text {hitung }}>r_{\text {tabel }}$ sebesar 0,349 .

\section{Uji Validitas Instrumen Kuesioner Skala Guttman}

Instrumen dalam penelitian ini menggunakan kuisioner dengan skala Guttman maka digunakan rumus Koefisien Reprodusibilitas (Coefficient of Reproducibility) dan Koefisien Skalabilitas (Coefficient of Skalability). Syarat penerimaan nilai koefisien reprodubilitas memiliki nilai > 0,90.(Masri Singarimbun, Sofian Effendi, 2014: 118-119). Syarat penerimaan nilai koefisien reprodusibiltas yaitu apabila koefisien reprodusibiltas memiliki nilai $>0.90$.

Didapatkan hasil dari jumlah responden 32 dengan jumlah potensi salah berjumlah 640 dan jumlah error sebesar 62, dengan Koefisien Reprodusibilitas ( $\mathrm{Kr}$ ) sebesar 0,90 dan Koefisien Skalabilitas (Ks) sebesar 0,81. Untuk perhitunganya digunakan aplikasi

\section{Al-Muqayyad}

Vol 4 No 2 (2021) 
SKALO (program analisis skala guttman), hasil perhitungan terlampir. Skala yang memiliki nilai $\mathrm{Kr}>0,90$ hasil uji instrumen ini dianggap baik untuk digunakan penelitian.

$\mathrm{Ks}=1-\left(\frac{e}{x}\right)$

Dimana:

Ks $=$ Koefisien Skalabilitas

e = Jumlah kesalahan/nilai error

$\mathrm{x} \quad=0,5$ ([Jumlah pernyataan dikali jumlah responden] - jumlah jawaban "ya").

Syarat penerimaan nilai koefisien skalabilitas yaitu apabila koefisien skalabilitas memiliki nilai > 0,60. (Asra, A., Irawan, P.B., \& Purwoto, 2016). Dianalisis dengan menggunakan Ms. Excel 2016 (hasil analisis terlampir pada Lampiran) yaitu:

a. $\mathrm{Kr}=0,90$ dimana $\mathrm{Kr}>0,90$, sehingga nilai koefisien reprodusibilitas diterima

b. $\mathrm{Ks}=0,81$ dimana $\mathrm{Ks}>0,60$, sehingga nilai koefisien skalabilitas diterima.

Sehingga dapat disimpulkan dari uji validitas menggunakan rumus Koefisien Reprodusibilitas (Coefficient of Reproducibility) dan Koesfisien Skalabilitas (Coefficient of Skalability) bahwa pada pernyataan dengan pembobotan menggunakan skala Guttman dinyatakan valid dan layak untuk dianalisis.

\section{Uji Reliabilitas}

Uji Reliabilitas Instrumen Kuisioner Skala Likert

Tabel I.2

Hasil Uji Reliabilitas Instrumen Skala Likert

\begin{tabular}{cccc}
\hline Variabel & $\begin{array}{c}\text { Item } \\
\text { Instrumen } \\
\text { Pertanyaan }\end{array}$ & $\begin{array}{c}\text { Data Koefisien } \\
\text { Cronbach's Alpha } \\
\text { of item Deleted }\end{array}$ & $\begin{array}{c}\text { Keterangan } \\
\text { Hasil }\end{array}$ \\
\hline Faktor Budaya & P1 & 0,638 & Reliabel \\
$\left(\mathrm{X}_{1}\right)$ & P2 & 0,617 & Reliabel \\
& P3 & 0,592 & Reliabel \\
& P4 & 0,573 & Reliabel \\
& P5 & 0,678 & Reliabel \\
& P6 & 0,685 & Reliabel \\
Faktor Sosial $\left(\mathrm{X}_{2}\right)$ & P7 & 0,581 & Reliabel \\
\hline & P1 & 0,664 & Reliabel \\
& P2 & 0,863 & Reliabel \\
& P3 & 0,657 & Reliabel \\
& P4 & 0,666 & Reliabel
\end{tabular}


Faktor-Faktor yang Mempengaruhi Perilaku ......

\begin{tabular}{|c|c|c|c|}
\hline & P5 & 0,620 & Reliabel \\
\hline & P6 & 0,688 & Reliabel \\
\hline \multirow{13}{*}{$\begin{array}{c}\text { Faktor Pribadi } \\
\qquad\left(\mathrm{X}_{3}\right)\end{array}$} & $\mathrm{P} 1$ & 0,722 & Reliabel \\
\hline & $\mathrm{P} 2$ & 0,744 & Reliabel \\
\hline & P3 & 0,766 & Relliabel \\
\hline & $\mathrm{P} 4$ & 0,730 & Reliabel \\
\hline & P5 & 0,780 & Reliabel \\
\hline & P6 & 0,751 & Reliabel \\
\hline & $\mathrm{P} 7$ & 0,800 & Reliabel \\
\hline & P8 & 0,740 & Reliabel \\
\hline & P9 & 0,741 & Reliabel \\
\hline & P10 & 0,775 & Reliabel \\
\hline & $\mathrm{P} 11$ & 0,717 & Reliabel \\
\hline & $\mathrm{P} 12$ & 0,745 & Reliabel \\
\hline & $\mathrm{P} 13$ & 0,727 & Reliabel \\
\hline \multirow{12}{*}{$\begin{array}{l}\text { Faktor Psikologi } \\
\qquad\left(\mathrm{X}_{4}\right)\end{array}$} & $\mathrm{P} 1$ & 0,737 & Reliabel \\
\hline & $\mathrm{P} 2$ & 0,728 & Reliabel \\
\hline & P3 & 0,727 & Reliabel \\
\hline & $\mathrm{P} 4$ & 0,740 & Reliabel \\
\hline & P5 & 0,860 & Reliabel \\
\hline & P6 & 0,794 & Reliabel \\
\hline & P7 & 0,857 & Reliabel \\
\hline & P8 & 0,744 & Reliabel \\
\hline & P9 & 0,748 & Reliabel \\
\hline & P10 & 0,741 & Reliabel \\
\hline & P11 & 0,734 & Reliabel \\
\hline & $\mathrm{P} 12$ & 0,724 & Reliabel \\
\hline \multirow{15}{*}{$\begin{array}{c}\text { Keputusan } \\
\text { Konsumen (Y) }\end{array}$} & $\mathrm{P} 1$ & 0,770 & Reliabel \\
\hline & $\mathrm{P} 2$ & 0,782 & Reliabel \\
\hline & P3 & 0,789 & Reliabel \\
\hline & $\mathrm{P} 4$ & 0,809 & Reliabel \\
\hline & P5 & 0,769 & Reliabel \\
\hline & P6 & 0,795 & Reliabel \\
\hline & P7 & 0,776 & Reliabel \\
\hline & P8 & 0,771 & Reliabel \\
\hline & P9 & 0,789 & Reliabel \\
\hline & P10 & 0,794 & Reliabel \\
\hline & $\mathrm{P} 11$ & 0,770 & Reliabel \\
\hline & P12 & 0,812 & Reliabel \\
\hline & P13 & 0,764 & Reliabel \\
\hline & P14 & 0,778 & Reliabel \\
\hline & P15 & 0,770 & Reliabel \\
\hline
\end{tabular}

Sumber: Data Primer yang diolah, 2021

\section{Al-Muqayyad}

Vol 4 No 2 (2021) 
Semua instrumen data penelitian sebagian besar terkait dengan faktor Budaya (X1), Faktor Sosial (X2), Faktor Pribadi (X3), Faktor Psikologi (X4), dan Keputusan Konsumen (Y) serta dapat diandalkan dan layak untuk dinilai.

\section{Uji Reliabilitas Instrumen Kuisioner Skala Guttman}

Untuk penyelesainnya menggunakan metode Kuder Richardson 20 (KR-20) dengan menggunakan Ms. Excel 2016 (hasil analisis terlampir pada Lampiran).

Dari analisis dengan menggunakan Ms. Excel 2016 diperoleh nilai reliabilitas / KR 20 sebesar $=0,93$, menurut Duwi Priyatno, nilai reliabilitas kurang dari 0,6 adalah kurang baik, sedangkan 0,7 dapat diterima dan di atas 0,8 adalah baik. Dapat disimpulkan bahwa nilai reliabilitas $=0,93>0,8$ (maka nilai reliabilitas baik). (Duwi Prayitno, 2010: 98)

\section{Uji Hipotesis}

Uji Parsial (Uji-t)

1) Diketahui nilai table dalam penelitian ini adalah sebesar 1,697 , dimana diketahui bahwa derajat kebebasan sebesar $31(\mathrm{dk}=32-1)$ dan tingkat signifikan $(\alpha)$ untuk uji satu pihak sebesar 0,05 .

2) Didapatkan nilai thitung pada variabel Faktor Budaya $\left(X_{1}\right)$ adalah sebesar 1,350, jika

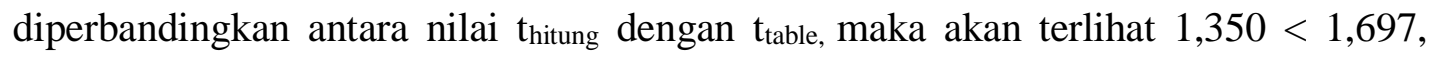
artinya $\mathrm{t}_{\text {hitung }}<\mathrm{t}_{\text {tabel. }}$. Hal ini menunjukkan bahwa $\mathrm{H}_{0}$ diterima dan $\mathrm{Ha}$ ditolak artinya tidak terdapat pengaruh signifikan antara faktor Budaya secara parsial antara perilaku Dosen STAI Auliaurrasyidin Tembilahan dalam memilih produk Bank Syariah.

3) Selanjutnya didapatkan pula nilai $t_{\text {hitung }}$ pada variabel Faktor Sosial $\left(\mathrm{X}_{2}\right)$ adalah sebesar 1,738, jika dibandingkan antara nilai thitung dengan $t_{\text {tabel, }}$ maka akan terlihat bahwa 1,783 $>1,697$, artinya $t_{\text {hitung }}>\mathrm{t}_{\text {tabel }}$. Hal ini menunjukkan bahwa Ha diterima dan $\mathrm{H}_{0}$ ditolak artinya terdapat pengaruh signifikan antara Faktor Sosial secara parsial terhadap perilaku Dosen STAI Auliaurrasyidin Tembilahan dalam memilih produk Bank Syariah.

4) Didapatkan nilai thitung pada variabel Faktor Pribadi $\left(X_{3}\right)$ adalah sebesar 1,457, jika

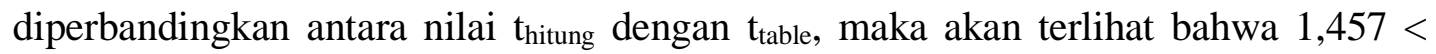
1,697, artinya $t_{\text {hitung }}<\mathrm{t}_{\text {tabel. }}$. Hal ini menunjukkan bahwa $\mathrm{H}_{0}$ diterima dan Ha ditolak artinya tidak terdapat pengaruh signifikan antara Faktor Pribadi $\left(\mathrm{X}_{3}\right)$ secara parsial terhadap perilaku Dosen STAI Auliaurrasyidin Tembilahan dalam memilih produk Bank Syariah.

5) Selanjutnya didapatkan pula nilai $t_{h i t u n g}$ pada variabel Faktor Psikologi $\left(X_{4}\right)$ adalah

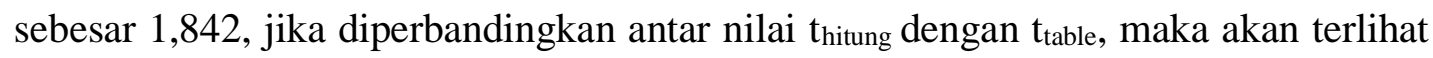
bahwa $1,842>1,697$, artinya $t_{\text {hitung }}>t_{\text {tabel }}$. Hal ini menunjukkan bahwa Ha diterima dan $\mathrm{H}_{0}$ ditolak artinya terdapat pengaruh signifikan antara Faktor Psikologi secara 
Faktor-Faktor yang Mempengaruhi Perilaku ......

parsial terhadap perilaku Dosen STAI Auliaurrasyidin Tembilahan dalam memilih produk Bank Syariah.

Uji Simultan (Uji-F)

1) Berdasarkan tabel harga distribusi $F$ (lihat pada lampiran) diketahui nilai Ftabel dalam penelitian ini adalah sebesar 2,730, dimana diketahui bahwa derajat kebebasan penyebut sebesar 27 (dkpenyebut $=32-4-1$ ) dan dkpembilang sebesar 4 dengan tingkat signifikan $(\alpha)$ sebesar $5 \%$.

2) Berdasarkan hasil uji-F, didapatkan nilai Fhitung adalah sebesar 10,247, jika diperbandingkan antara nilai Fhitung dengan Ftabel, maka akan terlihat bahwa 10,247 $>$ 2,730 artinya Fhitung > Ftabel. Hal ini menunjukkan bahwa Ha diterima dan H0 ditolak artinya terdapat pengaruh yang signifikan antara faktor-faktor yang mempengaruhi perilaku Dosen STAI Auliaurrasyidin Tembilahan secara simultan atau secara bersama-sama terhadap keputusan dalam memilih produk Bank Syariah.

\section{Hasil Uji Regresi}

Hasil Uji Analisis Persamaan Regresi Linier Berganda

Tabel I.3

Hasil Uji Analisis Persamaan Regresi Linier Berganda

\begin{tabular}{lcc}
\hline \multicolumn{1}{c}{ Model } & \multicolumn{2}{c}{ Unstandardized Coeficients } \\
& B & Std. Error \\
\hline (Constant) & 5,755 & 8,769 \\
Faktor Budaya (X1) & 0,722 & 0,535 \\
Faktor Sosial (X2) & 0,668 & 0,584 \\
Faktor Pribadi (X3) & 0,630 & 0,526 \\
Faktor Psikologi (X4) & 0,677 & 0,559 \\
\hline
\end{tabular}

a. Dependent Variable: Keputusan Konsumen (Y)

Sumber: Data olahan penelitian, 2021 (hasil uji SPSS pada lampiran)

1) Apabila variabel faktor-faktor yang mempengaruhi perilaku Dosen STAI Auliaurrasyidin Tembilahan diasumsikan 0 (nol) atau konstan, maka keputusan dalam memilih produk Bank Syariah bernilai 5,755

2) Faktor Budaya $\left(X_{1}\right)$ dengan nilai koefisien regresi adalah sebesar 0,722, artinya setiap peningkatan penerapan variabel faktor budaya sebesar 1 satuan maka akan meningkatkan keputusan Dosen STAI Auliaurrasyidin Tembilahan dalam memilih produk Bank Syariah sebesar 0,722 dengan asumsi variabel lainnya tetap.

3) Faktor Sosial $\left(\mathrm{X}_{2}\right)$ dengan nilai koefisien regresi adalah sebesar 0,668, artinya setiap peningkatan penerapan variabel faktor sosial sebesar 1 satuan maka akan meningkatkan keputusan Dosen STAI Auliaurrasyidin Tembilahan dalam memilih produk Bank Syariah sebesar 0,668 dengan asumsi variabel lainnya tetap.

4) Faktor Pribadi $\left(X_{3}\right)$ dengan nilai koefisien regresi adalah sebesar 0,630, artinya setiap peningkatan penerapan faktor pribadi sebesar 1 satuan maka akan meningkatkan 
keputusan Dosen STAI Auliaurrasyidin Tembilahan dalam memilih produk Bank Syariah sebesar 0,630 dengan asumsi valiabel lainnya tetap.

5) Faktor Psikologi $\left(\mathrm{X}_{4}\right)$ dengan nilai koefisien regresi adalah sebesar 0,677, artinya setiap peningkatan variabel karakteristik faktor psikologi sebesar 1 satuan maka akan meningkatkan keputusan Dosen STAI Auliaurrasyidin Tembilahan dalam memilih produk Bank Syariah sebesar 0,677 dengan asumsi variabel lainnya tetap.

Uji Analisis Koefisien Korelasi

Tabel I.4

Hasil Uji Analisis Koefisien Korelasi

\begin{tabular}{ccccc}
\hline Model & $\mathrm{R}$ & $\mathrm{R}$ Square & $\begin{array}{c}\text { Adjusted } R \\
\text { Square }\end{array}$ & $\begin{array}{c}\text { Std. Error of the } \\
\text { Estimate }\end{array}$ \\
\hline 1 & 0,776 & 0,603 & 0,544 & 1,79032 \\
\hline
\end{tabular}

Sumber: Data olahan penelitian, 2021 (hasil uji SPSS pada lampiran)

Berdasarkan data di atas, maka dapat dijelaskan bahwa tingkat pengaruh variabel faktor-faktor yang mempengaruhi perilaku Dosen STAI Auliaurrasyidin Tembilahan terhadap keputusan dalam memilih produk Bank Syariah bernilai 0,776 dan berdasarkan tabel interprestasi koefisien korelasi maka tingkat hubungannya dalam kategori "kuat" atau "tinggi" karena nilai korelasi berada dalam interval 0,60-0,799

Uji Analisis Koefisien Determinasi $\left(R^{2}\right)$

Selanjutnya seperti terlihat pada tabel I.4 di atas, pengaruh variabel terikat terhadap variabel bebas atau nilai determinannya $\left(\mathrm{R}^{2}\right)$ adalah sebesar 0,603 atau 60,30\%. Dalam situasi ini dapat ditarik kesimpulan bahwa faktor-faktor yang mempengaruhi perilaku Dosen STAI Auliaurrasyidin dalam memilih produk Bank Syariah sebesar $60,30 \%$. Faktor lain yang tidak termasuk dalam variabel model penelitian ini mempengaruhi sisanya sebesar $39,70 \%$.

Hasil Moderated Regresi Analisis (MRA) Variabel Pengetahuan (Z)

Uji Analisis Koefisien Kolerasi

Tabel I.5

Hasil Uji Analisis Koefisien Kolerasi

\begin{tabular}{ccccc}
\hline Model & $\mathrm{R}$ & R Square & $\begin{array}{c}\text { Adjusted } R \\
\text { Square }\end{array}$ & $\begin{array}{c}\text { Std. Error of the } \\
\text { Estimate }\end{array}$ \\
\hline 1 & 0,411 & 0,169 & 0,141 & 6,72503 \\
\hline
\end{tabular}

Sumber: Data olahan penelitian, 2021 (hasil uji SPSS pada lampiran)

Berdasarkan data di atas dapat ditarik kesimpulan bahwa tingkat pengaruh perilaku Dosen STAI Auliaurrasyidin Tembilahan dalam memilih produk Bank Syariah 
Faktor-Faktor yang Mempengaruhi Perilaku ......

terhadap variabel pemoderasi pengetahuan adalah sebesar 0,411, berdasarkan tabel interprestasi Koefisien Korelasi berada dalam kisaran 0,40 hingga 0,599, maka tingkat hubungannya berada pada kategori "sedang" atau "cukup".

\section{Uji Analisis Koefisien Determinasi (R2)}

Selanjutnya besarnya pengaruh antara variabel terikat dan variabel bebas, atau nilai determinannya $\left(\mathrm{R}^{2}\right)$, dapat diamati pada tabel I.5 di atas, yaitu 0,169 atau $16,90 \%$. Dalam hal ini besarnya pengaruh variabel pengetahuan sebagai moderasi terhadap perilaku keputusan Dosen STAI Auliaurrasyidin Tembilahan dalam memilih produk Bank Syariah adalah sebesar 16,90\%, dan jika digabungkan dengan pengaruh faktorfaktor yang mempengaruhi perilaku Dosen STAI Auliaurrasyidin Tembilahan sebelumnya yaitu $60,30 \%$, jadi nilai total determinan $\left(\mathrm{R}^{2}\right)$ adalah $77,20 \%$.

Pada keadaan ini besarnya pengaruh faktor-faktor yang mempengaruhi perilaku Dosen STAI Auliaurrasyidin Tembilahan dalam memilih produk Bank Syariah diperkirakan sebesar $77,20 \%$. Faktor-faktor lain yang tidak termasuk dalam variabel model penelitian ini, baik pada variabel utama maupun pada variabel moderasi, mempengaruhi sisanya sebesar $22,80 \%$.

\section{Faktor-faktor Yang Mempengaruhi Perilaku Dosen STAI Auliaurrasyidin Tembilahan Secara Parsial Terhadap Keputusan Memilih Produk Bank Syariah}

\section{Faktor Budaya}

Variabel budaya memiliki dampak yang paling luas dan mendalam. Komponen pertama yang menentukan perilaku, menurut Kotler, adalah faktor budaya. Pengaruh paling mendasar dari keinginan dan tindakan untuk memperoleh nilai, persepsi, preferensi, dan perilaku dari institusi yang signifikan adalah elemen budaya. Perilaku konsumen sangat dipengaruhi oleh pengaruh budaya. Budaya, subkultur, dan kelas sosial adalah semua variabel budaya. Budaya adalah penyebab paling mendasar dari keinginan dan tindakan. (Philip Kotler dan Kevin Lene Keller, 2016: 112)

Berdasarkan uji hipotesis parsial (uji-t) faktor budaya, tidak ada hubungan yang signifikan antara faktor budaya dengan keputusan Dosen STAI Auliaurrasyidin Tembilahan memilih produk Bank Syariah.

Annisa Wahyulkarimah (2018), temuan mengungkapkan bahwa layanan konsumen, promosi, dan pemahaman produk memiliki dampak menguntungkan yang kuat pada keputusan mereka menggunakan bank syariah. Sedangkan faktor budaya tidak berpengaruh terhadap keputusan nasabah untuk melakukan transaksi bank dengan lembaga syariah. Selanjutnya Ida Nurlaeli (2017), tingkat signifikasi variabel budaya sebesar 0,531>0,05 hal ini menunjukkan bahwa variabel budaya secara parsial tidak berpengaruh signifikan terhadap keputusan memilih Bank Syariah, sesuai hasil pengujian hipotesis dengan regresi berganda.

Pada analisa dan pembahasan dari hasil penelitian dengan pendekatan kualitatif bahwa secara keselurahan informen yang diwawancara mengenai Faktor Budaya yaitu 
kebiasaan masyarakat kecenderungan mengikuti tren perkembangan nama syariah dari segi agama dan kelas sosial.

Hal ini menunjukkan bahwa faktor budaya tidak mempengaruhi keputusan individu atau konsumen untuk memilih suatu produk, dan tentu saja, ini menetapkan fakta bahwa faktor budaya tidak selamanya dapat mempengaruhi keputusan pemilihan produk, memungkinkan faktor lain yang secara signifikan mempengaruhi perilaku konsumen dalam membuat keputusan pemilihan produk.

\section{Faktor Sosial}

Kelompok referensi, keluarga, serta peran dan status sosial konsumen semuanya merupakan pengaruh sosial. (Philip Kotler dan Gary Armstrong, 2016: 163) Sikap dan perilaku seseorang dipengaruhi oleh kelompok acuan, baik secara langsung maupun tidak langsung. Kelas sosial dapat berbentuk sistem kasta, di mana anggota kasta yang berbeda dapat mengubah keanggotaan kasta mereka untuk tugas-tugas tertentu, seperti ketika ingin memilih suatu produk. Pengaruh variabel sosial terhadap keputusan memilih suatu produk dapat dilihat pada hubungan dengan teman, keluarga, dan orang tua.

Berdasarkan uji hipotesis parsial (uji t) faktor sosial, terlihat bahwa faktor sosial memiliki pengaruh yang cukup besar terhadap keputusan Dosen STAI Auliaurrasyidin Tembilahan dalam memilih produk Bank Syariah. Temuan penelitian ini sesuai dengan penelitian sebelumnya.

Penelitian oleh Okta Nofri dan Andi Hafifah (2018), temuannya menganalisis bagaimana pengaruh perilaku konsumen terhadap keputusan pembelian produk online di Makassar. Penelitian kuantitatif mengungkapkan bahwa aspek sosial mempengaruhi keputusan belanja online dengan cara yang menguntungkan dan signifikan, baik secara bersamaan atau sebagian. Pertimbangan sosial adalah aspek terpenting yang mempengaruhi belanja online. Temuan penelitian menurut Adnan (2018) mengungkapkan bahwa variabel faktor sosial berpengaruh terhadap keputusan pembelian Susu Morinaga di Kota Lhokseumawe. Lebih lanjut Sunarto (2018) menemukan bahwa aspek sosial berpengaruh positif dan signifikan terhadap keputusan konsumen untuk membeli ponsel Xiaomi Redmi 3S di Jalan Bintara Raya Bekasi, berdasarkan temuan uji simultan dan parsial. Temuan ini menunjukkan bahwa semakin akurat model yang digunakan dalam penelitian ini, semakin besar kemungkinan konsumen untuk membeli smartphone Xiaomi Redmi 3S. Faktor sosial merupakan variabel yang paling dominan.

Sufitrayati, Fanny Nailufar (2018) menemukan bahwa variabel sosial berpengaruh besar terhadap keputusan konsumen dalam memilih Bank Syariah di Kota Banda Aceh. Sementara itu, Romiansyah, Sugiant, Tutik Yuliani (2019) menemukan bahwa faktor sosial mempengaruhi keputusan nasabah BNI syariah di kantor cabang Kota Balikpapan. Demikian pula menurut penelitian Muhammad Rizalun Nashoha (2019), faktor sosial dapat mempengaruhi keputusan memilih Bank syariah di Yogyakarta.

Pada analisa dan pembahasan dari hasil penelitian dengan pendekatan kualitatif bahwa secara keseluruhan informan yang diwawancara mengenai faktor sosial yaitu: 
Faktor-Faktor yang Mempengaruhi Perilaku ......

Karena tuntutan tempat kerja mengharuskan memakai rekening syariah sesuai pekerjaan di ekonomi syariah artinya peran dan status yang mempengaruhi

\section{Faktor Pribadi}

Kualitas pribadi mempengaruhi aspek pribadi, seperti keputusan konsumen. Hal ini logis karena dalam mengambil keputusan, konsumen selalu membutuhkan opini atau penguat opini. Faktor-faktor ini meliputi usia dan tahapan kehidupan, karier, keadaan ekonomi, gaya hidup, serta kepribadian dan konsep diri pembeli. ( Philip Kotler dan Gary Armstrong, 2016: 169). Perilaku pembelian seseorang juga dipengaruhi ciri-ciri kepribadian konsumen yang bersangkutan. Keteraturan psikologis dan efek lingkungan digabungkan dalam variabel pribadi. Termasuk di dalamnya watak dan landasan seseorang, terutama ciri-ciri dominannya. Terlepas dari kenyataan bahwa kepribadian adalah konsep berharga dalam menganalisis perilaku konsumen, beberapa pemasar merasa bahwa kepribadian berdampak pada jenis dan merek produk yang dibeli. Berbagai faktor, seperti pekerjaan, kondisi ekonomi, dan gaya hidup, mempengaruhi kepribadian seseorang. Semakin besar posisi seseorang di tempat kerja, serta status ekonomi dan gaya hidup yang baik, semakin besar kemungkinan mereka untuk memilih suatu produk.

Berdasarkan uji hipotesis parsial (uji-t) faktor Pribadi menunjukkan bahwa tidak terdapat pengaruh signifikan antara Perilaku Konsumen Faktor Pribadi secara parsial terhadap keputusan Dosen STAI Auliaurrasyidin Tembilahan dalam memilih bank Syariah. Hasil Penelitian ini sesuai dengan penelitian terdahulu yang dilakukan oleh Muhammad Rizalun Nashoha (2019) teknik deskriptif kuantitatif digunakan dalam penelitian ini. Data dianalisis menggunakan sofware IBM SPSS Amos dan analisis SEM tipe Covarian Based Structural Equation Modeling (CBSEM). Temuan penelitian ini menunjukkan bahwa aspek budaya, sosial, pribadi, dan psikologis dapat mempengaruhi keputusan secara keseluruhan untuk memilih Bank Syariah di Yogyakarta. Kecuali variabel pribadi, yang berpengaruh negarif dan tidak signifikan terhadap keputusan komunitas non-Muslim untuk menjadi nasabah Bank Syariah, semua hipotesis ditemukan diterima setelah mengevaluasi setiap variabel. Ketika korelasi masing-masing variabel diuji, korelasi terkuat ditentukan menjadi 0,642 antara budaya dan sosial.

Secara keseluruhan informan yang diwawancarai mengenai faktor pribadi yaitu: usia, selera, pekerjaan dan kondisi ekonomi, mempengaruhi pemilihan produk bank syariah karena sesuai dengan pendapatan gaji selain perilaku gaya hidup Islami, sedangkan kepribadian dan konsep diri tidak memiliki pengaruh, menurut hasil penelitian kualitatif.

\section{Faktor Psikologi}

Unsur-unsur psikologis, seperti motivasi seseorang, persepsi atau pandangan terhadap suatu objek, dan belajar dari pengalaman yang diperoleh seseorang untuk selanjutnya berperilaku terhadap objek pembelajaran tersebut. Perilaku konsumen dipengaruhi oleh persepsi yang merupakan salah satu sub faktor psikologis.

\section{Al-Muqayyad}

Vol 4 No 2 (2021) 
Berdasarkan uji hipotesis parsial (uji t) faktor psikologi, terlihat bahwa faktor psikologi berpengaruh signifikan secara parsial terhadap perilaku Dosen STAI Auliaurrasyidin tembilahan dalam memilih produk Bank Syariah. Hasil penelitian ini sesuai dengan temuan peneliti terdahulu

Hasil temuan Okta Nofri dan Andi Hafifah (2018), pengaruh perilaku konsumen terhadap keputusan pembelian produk online di Makassar. Penelitian kuantitatif mengungkapkan bahwa unsur-unsur psikologis mempengaruhi keputusan belanja online dengan cara yang menguntungkan dan signifikan, baik secara bersamaan atau sebagian. Demikian pula dengan Adnan (2018), temuan mengungkapkan bahwa faktor psikologi mempengaruhi keputusan pembelian susu Morinaga di Kota Lhokseumawe. Sunarto (2018) menemukan bahwa unsur psikologis memiliki pengaruh yang menguntungkan dan signifikan terhadap keputusan konsumen untuk membeli ponsel Xiaomi Redmi 3S di Jalan Bintara raya, Bekasi, berdasarkan hasil penelitian secara simultan dan parsial. Temuan ini menunjukkan bahwa semakin akurat model yang digunakan dalam penelitian ini, semakin besar kemungkinan konsumen untuk membeli smartphone Xiaomi redmi 3S.

Penelitian Sufitrayati dan Fanny Nailufar (2018), hasil penelitian menunjukkan bahwa faktor psikologis memiliki pengaruh yang signifikan terhadap keputusan nasabah dalam memilih Bank Syari'ah di Kota Banda Aceh. ternyata variabel faktor psikologi memiliki pengaruh paling signifikan terhadap keputusan nasabah bank Syari'ah. Demikian pula penelitian Romiansyah, Sugiant, Tutik Yuliani (2019) menemukan bahwa aspek psikologis mempengaruhi pengambilan keputusan nasabah BNI syariah di kantor cabang Kota Balikpapan. Elemen psikologis yang paling berpengaruh dalam pengambilan keputusan. Selanjutnya menurut penelitian Muhammad Rizalun Nashoha (2019), faktor psikologis mempengaruhi keputusan nasabah untuk menabung di Bank Aceh Syariah cabang Banda Aceh. dan penelitian Rafikah, Amrusi (2019), faktor psikologi mempengaruhi keputusan nasabah untuk menabung di Bank Aceh Syariah cabang Banda Aceh.

Dalam analisis dan pembahasan hasil penelitian dengan pendekatan kualitatif, secara keseluruhan informan yang diwawancarai mengenai faktor psikologi yaitu dari segi motivasi, persepsi produk Bank Syariah memberikan keuntungan yang wajar juga lebih halal dibandingkan produk konvensional dan mengikuti ketentuan perintah Allah SWT. Yaitu tidak menggunakan praktek riba.

Hal ini dapat dimaklumi karena keinginan atau permintaan seseorang terhadap suatu produk atau jasa cukup tinggi, dan konsumen selalu ini ingin dipuaskan. Akibatnya, motivasi psikologi, serta kepercayaan diri dan pengetahuan tentang apa yang harus dibeli, mempenngaruhi keputusan 
Faktor-Faktor yang Mempengaruhi Perilaku ......

Faktor-faktor Yang Mempengaruhi Perilaku Dosen STAI Auliaurrasyidin Tembilahan Secara Simultan Terhadap Keputusan Dalam Memilih Produk Bank Syariah

Berdasarkan uji hipotesis secara simultan (uji F), terdapat pengaruh yang signifikan antara faktor perilaku konsumen seperti faktor budaya, sosial, pribadi, dan psikologi terhadap keputusan Dosen STAI Auliaurrasyidin Tembilahan dalam memilih produk bank syariah baik secara bersamaan atau bersama-sama.

Secara keseluruhan informan yang diwawancarai membahas faktor-faktor yang mempengaruhi perilaku Dosen STAI Auliaurrasyidin dalam memilih produk bank syariah di Tembilahan dapat ditarik dengan baik dalam analisis dan pembahasan hasil penelitian dengan menggunakan pendekatan kualitatif. Berdasarkan hasil wawancara dapat disimpulkan bahwa selain faktor budaya, sosial, pribadi, psikologi dan pengetahuan, pembayaran gaji dari kepentingan administrasi, jangkauan akses, kemudahan, dan kenyamanan dalam pelayanan dan fasilitas merupakan faktor lainnya. yang mempengaruhi keputusan Dosen STAI Auliaurrasyidin Tembilahan dalam memilih produk Bank Syariah.

Hal ini sejalan dengan pemikiran Philip Kotler dan Gary Armstrong bahwa aspek perilaku konsumen seperti budaya, sosial, pribadi dan psikologis mempengaruhi keputusan konsumen dalam memilih produk bank syariah. (Philip Kotler dan Gary Armstrong, 2016: 179). Secara teori, ketika ingin memilih produk bank syariah, mereka akan memperhatikan dan mempertimbangkan pertimbangan tertentu sebelum memutuskan untuk memanfaatkan produk perbankan syariah. Pilihan konsumen terhadap produk bank syariah dipengaruhi oleh pertimbangan budaya. Aspek budaya, sosial, pribadi, psikologis, dan pengetahuan semuanya disertakan. Konsumen akan mencari kepuasan maksimal dalam memenuhi persyaratan dan keinginan konsumen, karena permintaan produk akan ditentukan oleh perilaku konsumen. Akibatnya, bank syariah harus dapat mengenali potensi ini dan dengan cepat memahami persyaratan dan keinginan konsumen, karean permintaan produk akan ditentukan oleh perilaku konsumen.

Studi tentang proses yang terlibat ketika individu atau kelompok memilih, membeli, dan menggunakan produk atau jasa yang sesuai dengan kebutuhan mereka dikenal sebagai perilaku konsumen. Untuk memahami konsumen dan merancang strategi pemasaran yang efektif, kita perlu mengetahui apa yang mereka pikirkan (kognisi), bagaimana perasaan mereka (pengaruh), apa yang mereka lakukan (perilaku), dan dimana (peristiwa) mempengaruhi dan dipengaruhi oleh apa yang mereka persepsikan. Konsumen berpikir, merasakan, dan bertindak dalam berbagai cara.

Manajer pemasaran yang sukses tidak hanya harus berkonsentrasi pada bagaimana membuat produk mereka terjual secara efektif, tetapi juga pada mengapa konsumen memilih produk yang mereka jual, terutama yang mencoba memahami perilaku konsumen, terutama elemen yang memengaruhi pengambilan keputusan dan perilaku. 
Memahami perilaku konsumen akan memungkinkan perusahaan untuk menciptakan pola komunikasi yang tepat melalui kegiatan promosi guna membujuk masyarakat untuk membeli produk.

Ada beberapa aspek yang mempengaruhi perilaku konsumen dalam membeli suatu produk atau jasa. Faktor-faktor perilaku konsumen, menurut Kotler dan Armstrong, meliputi pengaruh budaya, sosial, pribadi, dan psikologi.

Hasil pengujian secara simultan mengungkapkan bahwa aspek budaya, sosial, pribadi, dan psikologi memiliki pengaruh yang cukup besar terhadap keputusan konsumen untuk membeli ponsel Xiaomi Redmi 3S di Jalan Bintara Raya, Bekasi, menurut penelitian sebelumnya oleh Sunarto (2018). Tingkat pengaruh yang terungkap adalah $81,4 \%$, menunjukkan hubungan yang erat antara variabel-variabel tersebut dengan keputusan konsumen untuk membeli smartphone Xiaomi redmi 3S. Menurut penelitian Annisa Wahyulkarimah (2018), karakteristik layanan, periklanan, dan pemahaman produk memiliki dampak yang menguntungkan dan signifikan terhadap keputusan nasabah dalam memilih bank syariah.

\section{Variabel Moderasi Pengetahuan Terhadap Faktor-faktor Yang Mempengaruhi Perilaku Dosen STAI Auliaurrasyidin Tembilahan Dalam Memilih Produk Bank Syariah}

Berdasarkan uji analisis koefisien korelasi, tingkat pengaruh perilaku Dosen STAI Auliaurrasyidin Tembilahan dalam memilih produk Bank Syariah pada variabel pemoderasi pengetahuan adalah 0,411, dan koefisien kolerasi berada pada kisaran 0,040 sampai dengan 0,599, maka hubungan tersebut "sedang" atau "cukup"

Selanjutnya besarnya pengaruh antara variabel terikat dan variabel bebas, atau nilai determinannya $\left(\mathrm{R}^{2}\right)$, dalam hal ini besarnya pengaruh variabel pengetahuan sebagai moderasi terhadap perilaku keputusan Dosen STAI Auliaurrasyidin Tembilahan dalam memilih produk bank syariah adalah sebesar 16,90\%, dan jika digabungkan dengan pengaruh faktor-faktor yang mempengaruhi perilaku Dosen STAI Auliaurrasyidin Tembilahan sebelumnya $60,30 \%$, jadi nilai total determinan $\left(\mathrm{R}^{2}\right)$ adalah $77,20 \%$. Pada keadaan ini besarnya pengaruh faktor-faktor yang mempengaruhi perilaku Dosen STAI Auliaurrasyidin Tembilahan dalam memilih produk bank syariah diperkirakan sebesar $77,20 \%$. Faktor-faktor lain yang tidak termasuk dalam variabel model penelitian ini, baik pada variabel utama maupun pada variabel moderasi, mempengaruhi sisanya sebesar $22,80 \%$

Pada analisa dan pembahasan dari hasil penelitian dengan pendekatan kualitatif mampu digambarkan dengan baik bahwa secara keseluruhan informan yang diwawancara mengenai faktor-faktor yang mempengaruhi perilaku Dosen STAI Auliaurrsyidin Tembilahan dalam memilih produk bank syariah mengenai variabel pengetahuan sebagai moderasi dapat disimpulkan bahwa pengetahuan produk yang bervariasi mempengaruhi dari karakteristik produk, manfaat produk maupun selera. 
Faktor-Faktor yang Mempengaruhi Perilaku ......

Hal ini sesuai dengan teori pengetahuan berpengaruh terhadap konsumen dalam mengambil keputusan karena konsumen mengetahui dengan mengakses informasi melalui media sosial sehingga konsumen dapat dengan mudah memperoleh layanan serta mengetahui bagaimana cara membelinya. Pengetahuan konsumen, menurut Ujang Sumarwan, mencakup semua informasi yang dimiliki konsumen tentang berbagai produk dan layanan, serta pengetahuan lainnya terkait tentang produk dan layanan tersebut dan informasi tentang perannya sebagai konsumen. Pengetahuan konsumen berdampak pada apakah mereka membeli atau menggunakan barang atau jasa atau tidak. (Ujang Sumarwan, 2011: 147). Sumber informasi yang terdapat pada aplikasi (online) yang akan menghubungkan antara perbankan dengan konsumen sehingga dapat mengetahui produk yang diberikan. Semakin tahu seorang konsumen terhadap produk dan jasa keuangan maka semakin mempermudah konsumen dalam memilih produk bank syariah.

Kemudian menurut penelitian Annisa Wahyulkarimah (2018), veriabel product knowledge berpengaruh secara parsial terhadap keputusan nasabah memilih bank syariah. Demikian pula menurut Ida Nurlaeli (2017), variabel product knowledge secara parsial berpengaruh baik terhadap keputusan konsumen untuk memilih Bank Syariah BPRS di Banyumas. dan Simona Laura Dragosa, Cristian Mihai Dragosa, dan Gabriela Mihaela Muresanc melakukan penelitian (2020) temuan studi indeks pengetahuan asuransi sangat penting dalam membuat keputusan pembelian.

\section{SIMPULAN}

Berdasarkan uji hipotesis parsial (uji-t) Faktor Budaya, tidak ada hubungan yang signifikan antara Faktor Budaya yang mempengaruhi perilaku Dosen STAI Auliaurrasyidin Tembilahan dalam memilih produk bank syariah. Sedangkan berdasarkan uji hipotesis parsial (uji-t) Faktor Sosial, terlihat bahwa perilaku Dosen STAI Auliaurrasyidin dalam memilih produk bank syariah memiliki pengaruh yang cukup besar terhadap keputusan dalam memilih produk bank syariah. Sedangkan Faktor Pribadi menunjukkan bahwa tidak terdapat hubungan yang signifikan antara Faktor Pribadi perilaku Dosen STAI Auliaurrasyidin Tembilahan dalam memilih produk bank syariah, berdasarkan uji hipotesis secara parsial (uji-t). Dan berdasarkan uji hipotesis parsial (ujit) Faktor Psikologi, terlihat bahwa Faktor Psikologis memiliki pengaruh terhadap perilaku Dosen STAI Auliaurrasyidin Tembilahan dalam memilih produk bank syariah.

Berdasarkan uji hipotesis secara simultan (uji F), terdapat pengaruh yang signifikan antara faktor-faktor yang mempengaruhi perilaku Dosen STAI Auliaurrasyidin Tembilahan yaitu faktor budaya, faktor sosial, faktor pribadi dan faktor psikologi terhadap keputusan dalam memilih produk bank syariah baik secara bersamaan atau bersama-sama.

Berdasarkan uji analisis koefisien korelasi pengaruh faktor-faktor yang mempengaruhi perilaku Dosen STAI Auliaurrasyidin Tembilahan yaitu faktor budaya, faktor sosial, faktor pribadi, dan psikologi secara simultan terhadap keputusan dalam memilih produk bank syariah, bernilai 0,776 , dan berdasarkan tabel Interpestasi koefisien

\section{Al-Muqayyad}

Vol 4 No 2 (2021) 
korelasi maka tingkat hubungan berada pada kategori "kuat" atau "tinggi" karena nilai korelasi berada dalam interval 0,60-0,799. Sedangkan uji Analisis koefisien korelasi variabel moderasi pengetahuan, besarnya pengaruh variabel pemoderasi pengetahuan terhadap perilaku keputusan Dosen STAI Auliaurrasyidin Tembilahan dalam memilih produk bank syariah bernilai 0,411, menurut tabel Interprestasi koefisien korelasi tingkat hubungan berada pada kategori "sedang" atau "cukup" karena nilai korelasi berada dalam interval 0,40-0,599.

Menurut uji Analisis Koefisien Determinasi (R2) besarnya pengaruh faktor-faktor yang mempengaruhi perilaku Dosen STAI Auliaurrasyidin Tembilahan dalam memilih peoduk bank syariah adalah sebesar $60,30 \%$. Faktor lain yang tidak termasuk dalam variabel model penelitian ini mempengaruhi sisanya 39,70\%. Sedangkan faktor-faktor yang mempengaruhi perilaku Dosen STAI Auliaurrasyidin Tembilahan dalam memilih produk bank syariah memiliki pengaruh sebesar 16,90\% terhadap variabel pemoderasi pengetahuan, ditambah lagi faktor-faktor yang mempengaruhi perilaku Dosen STAI Auliaurrasyidin Tembilahan dalam memilih produk bank syariah sebelumnya yaitu 60,30 $\%$. Nilai total deterninan (R2) adalah 77,20 \%. Hal ini menunjukkan bahwa faktor-faktor yang mempengaruhi perilaku Dosen STAI Auliaurrsyidin Tembilahan dalam memilih produk bank syariah memiliki pengaruh sebesar 77,20\%. Fsktor-faktor lain yang tidak termasuk dalam variabel model penelitian ini, baik variabel utama maupun pada variabel moderasi, sisanya mempengaruhi sebesar $22,80 \%$.

\section{REFERENSI}

Adnan. (2018). Pengaruh Perilaku Konsumen terhadap Keputusan Pembelian Susu Morinaga di Kota Lhokseumawe, Jurnal Visioner \& Strategis, 7(2).

Asra, A., Irawan, P.B., \& Purwoto, A. (2016). Metode Penelitian Survei, Bandung: In Media.

Arifin, Z. (2010). Memahami Bank Syari'ah, Jakarta: Alvabet

Dragosa, S. L, Dragos, C. M. \& Muresanc, G. M. (2020), From Intention To Decision In Purchasing Life Insurance And Behavioural Factors, Journal of Behavioural and Experimental economics, 87, 101555

https://www.ojk.go.id/id/kanal/syariah/data-dan-statistik/statistik-perbankansyariah/default.aspx, Maret 2020.

Kasmir. (2015). Manajemen Perbankan, Edisi-Revisi, Jakarta: Rajawali Pers.

Kotler, P. \& Amstrong, G. (2012). Prinsip-prinsip Pemasaran Edisi 12, Jilid 1, Jakarta: Erlangga,

Kolter, P. \& Keller, K. L. (2016). “Manajemen Pemasaran”, Jakarta: Indeks

Nashoha, M. R. (2019). Pengaruh Faktor Kebudayaan, Sosial, Pribadi dan Psikologis terhadap Keputusan Memilih Bank Syariah di Kota Yogyakarta (Studi pada 
Faktor-Faktor yang Mempengaruhi Perilaku ......

Masyarakat Non-Muslim Kota Yogyakarta), At-Taradhi: Jurnal Studi Ekonomi, X (2), Desember P-ISSN: 1979-3804, E-ISSN: 2548-9941.

Nofri, O., \& Hafifah, A. (2018). Analisis perilaku konsumen dalam melakukan online shopping di kota Makassar. Jurnal Minds: Manajemen Ide dan Inspirasi, 5(1), 113-132.

Nurlaeli, I. (2017). Pengaruh faktor budaya, psikologi, pelayanan, Promosi dan pengetahuan tentang produk terhadap Keputusan nasabah memilih BPRS di banyumas. Islamadina: Jurnal Pemikiran Islam, 18(2), 75-106.

Prayitno, D. (2010). Teknik Mudah dan Cepat Melakukan Analisis Data Penelitian dengan SPSS, Yogyakarta: Gava Media

Rafikah, A., \& Razak, A. (2019). Keputusan Nasabah Menabung Pada Bank Aceh Syariah Cabang Banda Aceh. Jurnal Economica Didactica, 1(1), 53-74.

Romiansyah, R., Sugianto, S., \& Yuliani, T. (2019). Pengaruh Faktor Internal Terhadap Pengambilan Keputusan Nasabah Dalam Memilih Menabung Pada Bank Syariah. Jurnal Edueco, 2(1), 5-15.

Singarimbun, M. \& Effendi, S., (2014). Metode Penelitian survai, Jakarta: LP3ES

Sufitrayati, S. \& Nailufar, F. (2018). Faktor-Faktor Yang Mempengaruhi Keputusan Nasabah Dalam Memilih Bank Syari'ah Di Kota Banda Aceh, Ihtiyat, 2(1), September.

Sugiyono, (2014). Metode Penelitan Bisnis, Bandung: Alfabeta. , (2012). Statistika Untuk Penelitian, Bandung: CV. Alfa Beta Sukmadinata,

Sunarto, S. (2018). Analisis Perilaku Konsumen Terhadap Keputusan Pembelian Handphone Xiaomi Redmi 3S. Moneter-Jurnal Akuntansi dan Keuangan, 5(1), 35-43.

Wahyulkarima, A., Nurlaeli, I., \& Makhrus, M. (2018). Pengaruh Budaya, Psikologis, Pelayanan, Promosi, dan Pengetahuan tentang Produk Terhadap Keputusan Nasabah dalam Memilih Bank Syariah. Jurnal Hukum Ekonomi Syariah, 1(1), 5179. 